\title{
Impact of Personal Selling on the User Decision to Use the Services of @wifi.id
}

\author{
H. Hendrayati, D. Ramadita \\ Management Department, Faculty of Economic and Business Education \\ Unversitas Pendidikan Indonesia \\ Bandung - INDONESIA \\ heny_hendrayati@yahoo.com
}

\begin{abstract}
All aspects of life in today's society are connected to technology and information. Therefore, PT Telkom plc has launched a public wifi with a fast connection named @wifi.id. In the process of marketing, @wifi.id implements personal selling strategies for improving consumer decisions to access @ wifi.id, so that the company's revenue can be increased. This study aims to determine the effect of the personal selling to the decision to use the service of @wifi.id at Pasupati Park in Bandung. The sampling technique used was purposive sampling. The population is 3,600 people who are users of the service of @ wifi.id at the park, and the sample in this study consists of 100 respondents. The analysis technique used is the Pearson product moment correlation coefficient and simple linear regression analysis. The results show that personal selling of the users of @wifi.id service in Pasupati Park is in the middle category; while the decision to use the service of @wifi.id in Pasupati Park is at the high category. Correlation calculation results show an association with high levels or significant between personal selling and the decision to use the service of @wifi.id at Pasupati Park. The amount of influence on the decision to use personal selling is amounted to $48.02 \%$, while the remainder is equal to $51.98 \%$, influenced by other factors or variables that are not investigated.
\end{abstract}

Keywords: personal selling, purchasing decisions

\section{INTRODUCTION}

In the era of globalization, the rapid development of technology and information through the Internet gives a great contribution to all people. PT Telekomunikasi Indonesia, as the national telecommunications company and the pioneer of telecommunications in Indonesia, has launched a wifi product named Indonesia $\mathrm{WiFi}$, or better known by@wifi.id.

Indonesia $\mathrm{WiFi}$ is a public internet service based on WiFi/Hotspot technology, which is a network of broadband access to enjoy the high speed internet service, as well as a variety of other multimedia services. Indonesia WiFi (@wifi.id) also provides public internet services based on WiFi/Hotspot technology to support the acceleration and expansion of Indonesia's economic development, which has been declared by the Government of the Republic of Indonesia. One of them is to build 1,110 thousand spots of WiFi at a broadband speed of 100 Mbps through WiFi.ID Corner.

The spots with@wifi.id in the city are intended to facilitate the public to access services anywhere and anytime. However, in the process of marketing there are many constraints experienced by PT Telkom Indonesia in promoting WiFi Indonesia. One of them is how to access @ wifi.id that is not widely known by the public. In addition, the voucher for @ wifi.id is only obtained through agent of Telkom or at Plasa Telkom, so that people are hard to find it in public places.

\section{TABLE I. THE DATA OF TARGET AND REALIZATION OF @WIFI.ID VOUCHER SALES FOR THE PERIOD OF 2014 IN BANDUNG}

\begin{tabular}{|c|c|c|c|c|}
\hline Nr. & Month & Target & Realisazation & Achievement \\
\hline 1 & January & 186.295 & 21.913 & $11,76 \%$ \\
\hline 2 & February & 186.295 & 125.297 & $67,26 \%$ \\
\hline 3 & March & 186.295 & 58.630 & $31,47 \%$ \\
\hline 4 & April & 310.491 & 57.961 & $18,67 \%$ \\
\hline 5 & May & 310.491 & 29.646 & $9,55 \%$ \\
\hline 6 & June & 310.491 & 122.759 & $39,54 \%$ \\
\hline 7 & July & 372.589 & 19.695 & $5,29 \%$ \\
\hline 8 & August & 372.589 & 28.533 & $7,66 \%$ \\
\hline 9 & September & 372.589 & 54.075 & $14,51 \%$ \\
\hline 10 & Oktober & 22.482 & 47.326 & $210,51 \%$ \\
\hline 11 & November & 22.482 & 68.490 & $304,64 \%$ \\
\hline 12 & December & 22.482 & 41.103 & $182,83 \%$ \\
\hline
\end{tabular}

In the Table 1 above, it can be seen that the company's targets in selling product of Voucher Spin Card @wifi.id in 2014 cannot be achieved until September 2014. Therefore, in October 2014, the company began to lower its targets from the initial target. Therefore, in October 2014 until December 2014, the company began to realize the sales target.

The lack of promotion of the service of @wifi.id is one factor that affect the lack of public knowledge. Another problem is the lack of public understanding about the @wifi.id and its use, especially in places where access of Free WiFi is installed. Several thematic parks in Bandung is mounted Free WiFi entitled Bandung Juara.

From the data in Table 2, it can be seen that, in some parks, there are Access Point of @wifi.id that its usage is little or even 0 (unused). From the data, it can also be seen that the Pasupati park has lowest usage number. In fact, Pasupati Park has a fairly high traffic. Its location is also quite strategic. Low levels of usage and the low number of consumers indicate that there has been a problem in the decision to use the service of @ wifi.id. PT Telkom has constructed marketing strategies to promote the service of @wifi.id. 
TABLE II. DATA OF WIFI.ID CORNER LOWEST USAGE IN PARKS OF BANDUNG

\begin{tabular}{|c|c|c|c|c|c|c|c|c|}
\hline $\begin{array}{l}\mathbf{N} \\
\mathbf{r}\end{array}$ & $\begin{array}{c}\text { Locati } \\
\text { on }\end{array}$ & Spin & $\begin{array}{l}\text { Usage } \\
\text { Spin }\end{array}$ & $\begin{array}{l}\text { Rev } \\
\text { enue } \\
\text { Spin }\end{array}$ & $\begin{array}{l}\text { To } \\
\text { tal } \\
\text { Us } \\
\text { er }\end{array}$ & $\begin{array}{c}\text { Tr } \\
\text { affi } \\
\text { c } \\
\text { (M) } \\
\text { B) }\end{array}$ & $\begin{array}{c}\text { Thr } \\
\text { oug } \\
\text { hput } \\
\text { (kpb } \\
\text { s) }\end{array}$ & $\begin{array}{l}\text { St } \\
\text { at } \\
\text { u } \\
\text { s }\end{array}$ \\
\hline 1 & $\begin{array}{l}\text { Taman } \\
\text { Lansia }\end{array}$ & 5,00 & 0,00 & $\begin{array}{l}7.00 \\
0,00\end{array}$ & $\begin{array}{l}32, \\
00\end{array}$ & $\begin{array}{c}15 . \\
97 \\
8,5 \\
9\end{array}$ & $\begin{array}{l}1.44 \\
3,60\end{array}$ & $\begin{array}{l}D \\
O \\
W \\
N\end{array}$ \\
\hline 2 & $\begin{array}{c}\text { Taman } \\
\text { Pasupa } \\
\text { ti } \\
\text { (Tama } \\
\text { n } \\
\text { Jombl } \\
\text { o) }\end{array}$ & 3,00 & 0,00 & 0,00 & $\begin{array}{l}11, \\
00\end{array}$ & $\begin{array}{c}19 . \\
06 \\
0,1 \\
6\end{array}$ & $\begin{array}{c}101, \\
79\end{array}$ & $\begin{array}{c}D \\
O \\
W \\
N\end{array}$ \\
\hline 3 & $\begin{array}{c}\text { Taman } \\
\text { Flexi }\end{array}$ & 1,00 & 0,00 & 0,00 & $\begin{array}{l}42, \\
00\end{array}$ & $\begin{array}{c}17 . \\
24 \\
8,6 \\
3\end{array}$ & $\begin{array}{c}124, \\
74\end{array}$ & $\begin{array}{l}D \\
O \\
W \\
N\end{array}$ \\
\hline 4 & $\begin{array}{c}\text { Taman } \\
\text { Dago } \\
\text { Cikapa } \\
\text { yang } \\
\text { Taman } \\
\text { Film }\end{array}$ & 7,00 & 0,00 & 0,00 & $\begin{array}{l}32, \\
00\end{array}$ & $\begin{array}{c}13 . \\
34 \\
6,5 \\
3 \\
51 . \\
91 \\
2,5 \\
9\end{array}$ & $\begin{array}{c}159 \\
27\end{array}$ & $\begin{array}{l}D \\
O \\
W \\
N \\
D \\
O \\
W \\
N\end{array}$ \\
\hline
\end{tabular}

One of the marketing strategies is by increasing the role of marketing promotion strategies that shape consumer understanding of the product and may affect consumers individually or better known by personal selling. The role of the salesperson to market @ wifi.id is considered suitable to build understanding of potential customers directly and to create a good relationship with the consumers.

\section{PROBLEM STATEMENT}

To identify the description of personal selling promotion conducted by PT Telkom Indonesia to market product of @ wifi.id at Pasupati Park in Bandung.

To reveal the decision to use the service of @wifi.id at Pasupati Park in Bandung.

To determine the influence of the promotion of personal selling to the decision to use the service of @ wifi.id at Pasupati Park in Bandung.

\section{THEORETICAL FRAMEWORK}

Personal selling, or individual sales, is the most famous way of promotion. Personal selling method is known and performed by almost all companies all over the world to sell their products and services to consumers. Personal selling is done to communicate with potential customers directly. Personal selling is a personal whose responsibility to make sales and building customer relationships [3]. Personal Selling is a person whose influence potential buyers to purchase products or services of the company, or provide feedback [1].

Meanwhile personal selling is a direct communication between sellers and prospective customers to introduce the product to potential customers and to establish customer understanding of the product so that they then try and buy it [5].
From the above definitions, it can be said that the personal selling is an effective way to attract potential buyers. The two-way communication benefits both parties (seller and prospective buyer).

In understanding consumer behavior, many influences underlie a person in making purchasing decisions of a product or a brand. Mostly, consumer's buying behavior is often influenced by many external stimuli, either in the form of marketing stimuli and environmental stimuli. The stimulation is then processed in accordance with personal characteristics before the purchasing decision is derived.

Purchasing decisions are based on how consumers feel the price and what they consider as the appropriate price, not the price adjusted by marketers [3]. Consumer buyer behavior is the buying behavior of the final consumerindividuals and Households who buy goods and services for personal consumption [2].

Based on the above definitions that have been described, it can be said that the purchase decision is the final step in the marketing process where the consumer determines the choice between several alternative options.

There are some dimensions in a purchase decision, which are Product Selection, Brand Selection, Distribution Channels Selection, Purchase Timing, Purchase Amount and Payment Method [3]. Personal selling is the most effective tool at Certain stages of the buying process, particularly in building up buyers preferences, convictions, and actions. It involves personal interaction between two or more people, so each person can Observe the others needs and characteristics and the make quick adjustments [2].

Promotion through personal selling has either direct effect that is incurred in face-to-face meeting between the seller and the buyer. There is communication about the facts needed to influence purchasing decisions. It is to persuade and to encourage the consumer purchasing decisions making.

Hypothesis: The hypothesis of this study is "There is Effects of Personal Selling on the Decision to Use the Service of @wifi.id of PT Telkom Indonesia.

\section{RESEARCH METHODOLOGY}

This research analyzes the influence of personal selling to the decision to use the service of @wifi.id. The object of study as an independent variable is personal selling $(\mathrm{X})$; while buying decision $(\mathrm{Y})$ is the dependent variable.

The population in this study is the users of $\mathrm{WiFi}$ at Pasupati Park, Bandung City. The population studied in this research is the total number of users of @ wifi.id per month in the park, amounted to 300 users in average. It means that there are 3600 users in a year. Subsequently, the population in this study is 3600 users of @ wifi.id in 2014. The number of samples studied is based on calculations by using the solving formula. The number of samples studied is 100 users. Accordingly, sample will be taken from 100 people.

The sampling technique used in this study is Non Probability Sampling. In non-probability sampling, elements in the population do not have the same opportunities to be elected as subject in the sample [5]. 
Purposive sampling is done by taking a sample from a population based on certain criteria. The criteria used may be based on certain considerations or specific quotas. The reason for taking the purposive sampling is that the sample criteria is in accordance with the needs of the research

Simple linear regression analysis was used to predict changes in the value of the dependent variable when the independent variable is increased or decreased. Simple linear regression analysis is based on the functional relationship or causal of one independent variable with one variable.

\section{RESULTS AND DISCUSSION}

Recapitulation of scores on personal selling variable according to the responses of @wifi.id service users at the park in Bandung is as follows.

TABLE III. RESPONDENTS RESPONSES ON PERSONAL

\begin{tabular}{|c|c|c|c|c|}
\hline $\mathrm{Nr}$ & $\begin{array}{c}\text { Indicator } \\
\text { Personal } \\
\text { Selling }\end{array}$ & $\begin{array}{c}\text { Number of } \\
\text { Questions }\end{array}$ & $\begin{array}{c}\text { Total } \\
\text { Score }\end{array}$ & $\begin{array}{c}\text { Average } \\
\text { Score }\end{array}$ \\
\hline 1 & $\begin{array}{c}\text { Prospecting and } \\
\text { Qualifying }\end{array}$ & 2 & 663 & 331 \\
\hline 2 & Pre-Approach & 2 & 691 & 345 \\
\hline 3 & $\begin{array}{c}\text { Presentation } \\
\text { and } \\
\text { Demonstration }\end{array}$ & 3 & 1050 & 350 \\
\hline 4 & $\begin{array}{c}\text { Overcoming } \\
\text { Objections }\end{array}$ & 2 & 635 & 317 \\
\hline 5 & Closing & 2 & 692 & 346 \\
\hline 6 & $\begin{array}{c}\text { Follow up and } \\
\text { Maintenance }\end{array}$ & 2 & 683 & 341 \\
\hline & Total & 13 & 4414 & 2030 \\
\hline
\end{tabular}

${ }^{\text {b. }}$ Source: Data processing results of the questionnaire, 2015

According to the recapitulation of scores on the variables of personal selling, it is found that the biggest score is the indicator of presentation and demonstration with a total score of 1050; and the average score of 350 . The lowest indicator is Overcoming Objections with a total score of 635; and an average score of 317. From the data obtained, it can be concluded that personal selling done by the salespeople of PT Telkom to market their products are best when they do presenting and communicating the benefits of its products and to create buying interest. The salesperson's role in overcoming the objections felt is still lack since seen there is a number of respondents who disagree on the question in the indicator of Overcoming Objections.

Based on recapitulation data of the variable of decision to use service of @wifi.id, the indicator with the highest score is the selection of products with an average score of 361, which means the indicator of the selection of products is an indicator variable that is most influential in the decision to use the service of @ wifi.id. It shows that the majority of respondents chose to use the service of @ wifi.id for the excellence of the products offered. They are the internet speed, large quota, and the appeal of the promotion. The indicator with the lowest score is the determination of the amount of the purchase with an average score of 315 . That is because most of the respondents are already using a smartphone with internet package so they do not require service of @wifi.id.
Therefore, allegedly, the majority of respondents would rather use the service of @wifi.id at certain moments when they need high-speed internet.

TABLE IV. RESPONDENT RESPONSES REGARDING

\begin{tabular}{|c|c|c|c|c|}
\hline $\mathrm{Nr}$ & $\begin{array}{l}\text { Indicator of } \\
\text { Decision to Use } \\
\text { the Services }\end{array}$ & $\begin{array}{c}\text { Number of } \\
\text { Questions }\end{array}$ & Total Score & \begin{tabular}{|c}
$\begin{array}{c}\text { Average } \\
\text { Score }\end{array}$ \\
\end{tabular} \\
\hline 1 & Product Selection & 3 & 1084 & 361 \\
\hline 2 & Brand Selection & 2 & 703 & 351 \\
\hline 3 & $\begin{array}{l}\text { Distribution } \\
\text { Channels } \\
\text { Selection }\end{array}$ & 2 & 632 & 316 \\
\hline 4 & Purchase Timing & 2 & 721 & 360 \\
\hline 5 & Purchase Amount & 1 & 315 & 315 \\
\hline 6 & Payment Method & 1 & 318 & 318 \\
\hline & Total & 11 & 3773 & 2021 \\
\hline
\end{tabular}

TABLE V. OUTPUT CORRELATION

\begin{tabular}{|c|c|c|c|}
\hline \multicolumn{4}{|c|}{ Correlations } \\
\hline & & $\begin{array}{c}\text { Decision to } \\
\text { Use the } \\
\text { Service }\end{array}$ & $\begin{array}{c}\text { Personal } \\
\text { Selling }\end{array}$ \\
\hline \multirow{2}{*}{$\begin{array}{c}\text { Pearson } \\
\text { Correlation }\end{array}$} & Decision to Use the Service & 1,000 & 693 \\
\hline & Personal Selling & 693 & 1,000 \\
\hline \multirow[t]{2}{*}{ Sig. (1-tailed) } & Decision to Use the Service & . & ,000 \\
\hline & Personal Selling &, 000 & . \\
\hline \multirow[t]{2}{*}{$N$} & Decision to Use the Service & 100 & 100 \\
\hline & Personal Selling & 100 & 100 \\
\hline
\end{tabular}

Based on the correlation data in Table 5, it can be seen that the correlation coefficient between personal selling with the decision to use is 0.693 with significance of 0.00 . Due to the significance level obtained is $<0.05$, then $\mathrm{H} 0$ is rejected and $\mathrm{H} 1$ is accepted. From the calculation by using the software SPSS 22.0 for Windows, it is obtained that the correlation coefficient between variables of personal selling and the decision to use is amounted to 0.693 . Based on the table of correlation interpretation, the correlation coefficient of 0.693 is in the interval from 0.600 to 0.799 , or is at a high level of influence. It shows that there is a strong influence between the variables of personal selling $(\mathrm{X})$ with the decision to use $(\mathrm{Y})$.

TABLE VI. REGRESSION COEFFICIENTS OUTPUT COEFFICIENTS $^{\text {A }}$

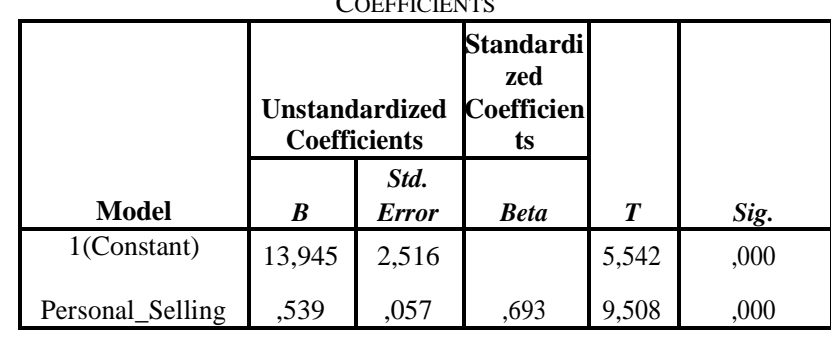

e. e. a. Dependent Variable: Decision to use service

The results obtained from the regression equation is as follows.

$$
\Psi=13.945+539 \Xi
$$


The constant value in the above equation is 13.945 . This value indicates that if there is no personal selling, the decision to use @ wifi.id on Pasupati Park is only at 13.945. Personal selling regression coefficient is 539, which means the rise on personal selling of the unit will be an increase in the decision to use amounted to 539.

The results of the data processing above show that personal selling positively influences on the decision to use @wifi.id at Pasupati Park, Bandung. It is equal to $48.02 \%$, while the remainder is equal to $51.98 \%$-influenced by other factors or variables not examined here.

\section{A. Hypothesis test (t test)}

To see the level of significance of the correlation coefficient between independent variables with the dependent variable, hypothesis test is required. The hypothesis test is $\mathrm{t}$ test. The $\mathrm{t}$ test was conducted to test the hypothesis of correlation between the independent variable and the dependent variable individually. The following are the significant value of $\mathrm{t}$ test:

TABLE VII. VALUE SIGNIFICANCE TEST T

TABLE VIII. COEFFICIENTS ${ }^{\mathrm{A}}$

\begin{tabular}{|c|c|c|c|c|c|}
\hline \multirow[b]{2}{*}{ Model } & \multicolumn{2}{|c|}{$\begin{array}{c}\text { Unstandardized } \\
\text { Coefficients }\end{array}$} & \multirow{2}{*}{\begin{tabular}{|c|}
$\begin{array}{c}\text { Standardi } \\
\text { zed } \\
\text { Coefficien } \\
\text { ts }\end{array}$ \\
Beta \\
\end{tabular}} & \multirow[b]{2}{*}{$T$} & \multirow[b]{2}{*}{ Sig. } \\
\hline & $B$ & $\begin{array}{c}\text { Std. } \\
\text { Error }\end{array}$ & & & \\
\hline 1 (Constant) & 13,945 & 2,516 & & 5,542 &, 000 \\
\hline Personal_Selling &, 539 & ,057 & ,693 & 9,508 &, 000 \\
\hline
\end{tabular}

a. Dependent Variable: Decision to use service

In the above table, it is known that the $\mathrm{t}$ count of personal selling is 9.508. the t table with a significance level of $5 \%$ is 1.66055 . It can be concluded that the $\mathrm{H} 0$ is rejected and the $\mathrm{H} 1$ accepted. That means the regression coefficient is significant. There is a positive and significant influence between personal selling with the decision to use the service of @wifi.id at Pasupati Park, Bandung.

\section{CONCLUSION}

In personal selling variable that consists of six indicators (Prospecting and Qualifying, Pre-Approach, Presentation and Demonstration, Overcoming Objections, Closing and Follow-up and Maintenance), the problems is found in the indicator of Overcoming Objections or salesperson's ability to overcome objections. The variable of Overcoming Objections is to get the lowest score so that it is known that the salesperson's role in overcoming the objection is still low. This shows that people are still unsure about the role of the salesperson to deal with complaints properly. The highest indicator in personal selling is the presentation and demonstration. From these results, it is known that most respondents pay more attention to presentation and demonstration in an individual sales and salesperson of PT Telkom. The @ wifi.id is considered able to have a good presentation so that potential customers are interested to listen and able to create buying interest. Results from this study can be concluded that consumers' assessment of personal selling variable is in the moderate category and quite good.

In the variable of decision to use there are 6 indicators, including the product selection, brand selection, purchase channel selection, purchase timing, the determination of the purchase amount, and the determination of payment methods. The level of the decision to use is at the high category. This is evidenced by the acquisition of the score obtained. Of the six indicators, the highest score is the indicator of the product selection. It means that most respondents use the service of @wifi.id because of the product excellence, such as internet speed, large quota, and exciting promotions. The determination of the number of purchases is the lowest indicator of these variables. It shows that most respondents only use the service of @ wifi.id at certain times according to the needs.

From the study, it can be concluded that there are positive influence between personal selling with the decision to use the service of @ wifi.id including a high degree of correlation.

\section{REFERENCES}

[1] E. Belch, George, A. Belch, Michael. 2012. Advertising and Promotion. Jakarta

[2] Kotler, Philip\& Armstrong, Gary. 2013. "Principles of Marketing" (14th Edition). Pearson, New Jersey

[3] Kotler, Philip \& Keller, Kevin Lane 2012. "Marketing Management" (14th Edition). New Jersey: Prentice Hall

[4] Silalahi, Ulber 2009. Metode Penelitian Sosial. Bandung; PT. Refika Aditama

[5] Tjiptono, Fandy.2008. "Brand Management and Strategy". Yogyakarta: Andi

[6] Official Data of PT Telkom Indonesia 